\title{
Ichthyoplankton of The Shelf and Deep Water Areas of the North and Northeast of the Black Sea in The Spring Season
}

\author{
Tatyana Klimova ${ }^{1}$, Irina Vdodovich ${ }^{1}$, Polina Podrezova ${ }^{1, *}$ (1)
}

${ }^{1}$ Russian Academy of Sciences, A.O. Kovalevsky Institute of Biology of the Southern Seas, MRO IBSS, Leninskii ave., 38/3, Moscow, 119991, Russian Federation

How to cite

Klimova, T., Vdodovich, I., Podrezova, P. (2021). Ichthyoplankton of The Shelf and Deep Water Areas of the North and Northeast of the Black Sea in The Spring Season. Turkish Journal of Fisheries and Aquatic Sciences, 21, 255-263. http://doi.org/10.4194/1303-2712-v21_5_05

\section{Article History}

Received 19 May 2020

Accepted 25 February 2021

First Online 03 March 2021

\section{Corresponding Author}

Tel.: +79788015840

E-mail: polyklim@gmail.com

\section{Keywords}

Ichthyoplankton

Species Composition

Spatial Distribution

Fish Larvae Feeding

\begin{abstract}
This paper is focused on the ichthyoplankton species composition and spatial distribution in the Black sea shelf zone and the deepwater regions off Crimean Peninsula and coast of the Caucasus during the spring hydrological season. Recent changes in the hydrological regime of the Black sea induced by the climate warming have led to an extension of the active and productive spawning of the dominant temperate-water species Sprattus sprattus until the end of the spring hydrological season. An intensive spawning of sprat was detected in March, April and May 2016, 2017 and 2019, which was confirmed by a predominance of younger age group larvae. The maximum number of eggs reached $224 \mathrm{ind} . / \mathrm{m}^{2}$, and the larvae - $116 \mathrm{ind} . / \mathrm{m}^{2}$. The wide size range of larvae as well as the low proportion of larvae with empty guts evidenced a favorable fodder base for their survival. The reduction in the age and sizeweight composition of sprat stock in the Black sea observed since 2016 as a result of an increase in its commercial fishing on the shelf of the Crimean Peninsula, did not affect sprat' spawning activity.
\end{abstract}

\section{Introduction}

Climate change is one of the key factors leading to latitudinal and altitudinal shifts in the spatial distribution of species as a result of changes in environmental conditions and their habitat suitability (Parmesan \& Yohe, 2003; Chen, Hill, Ohlemüller, Roy, \& Thomas, 2011; Weinert et al., 2016). In marine ecosystems global climate change can affect a variety of physicochemical properties of environment with potentially wideranging biological effects on physiology, phenology, adaptation, spatial distribution, changes in species structure, and trophic relationships within the aquatic organisms community (Cushing, 1995; Walther et. al., 2002; Brierley \& Kingsford, 2009; Hoegh-Guldberg \& Bruno, 2010; Doney et al., 2012; Hewitson et al., 2014). Higher temperatures change the time and duration of spawning of both thermophilic and temperate fish species in the seas with clearly defined seasonality. Shifts in spawning phenology and distribution of some benthic and pelagic fish species were recognized and reported for the North and Irish Seas (Perry, Low, Ellis, \& Reynolds, 2005; Engelhard, 2013; Jansen \& Gislason, 2011; Fincham, Rijnsdorp, \& Kröncke et al., 2011; Weinert et al. 2016; McQueen \& Marshall, 2017), Western English Channel (Genner et al. 2010), northeast Pacific Ocean (Ware \& Tanasichuk, 1989; Auth, Daly, Brodeur, \& Fisher, 2017;). The increase of the sea surface temperature (SST) of the Black sea, which has been observed since the beginning of the 1990s, contributed to an increase in the heat reserve in the layer 0-100 m (Oguz, Cokacar, Malanotte-Rizzoli, \& Ducklow, 2003; Belokopytov, 2017). This likely to have had a positive impact on the plankton community state and contributed to the extension of the spawning season of mass short-cycle fish species, both temperate 
and thermophilic, on the autumn hydrological season in the Black Sea (Klimova, Anninskyi, Vdodovich \& Podrezova, 2018; Klimova \& Podrezova, 2018). Studies on ichthyoplankton were conducted in the southern part of the Black sea as well (Satılmış et al., 2009; Satılmış et al., 2014; Şahin \& Duzgunes, 2019).

The most abundant species in ichthyoplankton of the Black Sea are the temperate short-cyclic planktophage $S$. sprattus in winter and the thermophilic Engraulis encrasicolus (Linnaeus, 1758) in the summer season. The autumn and spring hydrological seasons belong to the "off-season" period, when the fish eggs are found in single specimens, and the larvae are represented by an older age group. However, in recent years, intensive mass spawning of a temperate-water species $S$. sprattus off the Crimean peninsula begins in November, and the productive spawning of thermophilic E. encrasicolus continues in October (Klimova, Vdodovich, \& Anninskyi, 2010; Klimova et al., 2018; Klimova \& Podrezova, 2018), which has not been reported before in literature for this region (Dekhnik, 1973). The average number of sprat eggs and larvae in November 2017 was comparable to the maximum number of sprat eggs at the peak of the winter spawning season in December-January 1958-59. (Dekhnik, 1973; Klimova et al., 2018).

The results obtained in ichthyoplankton studies, it would seem, are not consistent with the data on the sprat fishery in 2016-2017. According to Shlyakhov, Shlyakhova, Nadolinsky, and Perevalov (2018), there was a dramatic decrease in sprat fisheries catches from 25943 tons in 2015 and 2016 down to 14782 tons in 2017, with the fish size and weight characteristics changing in favor of younger age groups. Fishing is known to make populations more sensitive to climate change by reducing abundance, density and truncating the age distribution (Ottersen et al., 2006). Thus, in 2015 , the share of younger age group of sprat (age $0+$ to $1+$ ) in the Black sea did not exceed $40.1 \%$, whereas in 2016-17 it was about 65\%, and sprat fish at the age of 4 years were almost absent in the fisheries catches (Shlyakhov et al., 2018). However, according to the age structure, the sprat population, as well as anchovy, is classified as a type with a pronounced predominance of younger age groups over older ones or "predominance of recruitment over the remainder" (Monastyrsky, 1952). Thus, in the period from 1956 to 1968 off the Romanian coast the younger age group of $S$. sprattus population (aged 0+ to $1+$ ) predominated over the older ones, accounting for 51.3 to $99.9 \%$, average $64 \%$ (Ivanov, Kostyuchenko \& Kautish, 1979), which is comparable to the data of 2016-17 (Shlyakhov et al., 2018). According to the data of small-cell trawl catches across the entire Black sea, the younger and older age groups of the sprat population in 1974-1975 consisted of equal shares (Ivanov et al., 1979). Sprat reaches sexual maturity by the age of 10 months and under favorable temperature and feeding conditions spawns throughout the year: in winter it spawns across the entire oxygen layer, and in summer - in the cold intermediate layer under the thermocline (Aleev, 1958; Oven, 1979; Giragosov, Zuev, \& Repetin, 2006). The younger age group seemed to provide a high intensity of spawning in November 2017, which was indirectly confirmed by a decrease in the size of the larvae of the younger age groups (Klimova et al., 2018). The eggs of young females are usually smaller, therefore, the size composition of larvae decreases when hatching (Aleev, 1956). On the one hand, the size of the hatching larvae in November 2017 (Klimova, et al., 2018) had been likely to decrease due to a change in the age composition of the spawning individuals in favor of the younger age group. On the other hand, it could have resulted from the reduced period of embryonic and post-embryonic development against the background of a relatively high water temperature in the sea during the spawning period. According to Petereit (2009), the transition to mixed nutrition (pigmentation of the eye and opening of the mouth) of Baltic sprat reduces by ten days with an increase in temperature from 3.8 to $13^{\circ} \mathrm{C}$, and for European sprat, with an increase in temperature from $10^{\circ}$ to $13^{\circ} \mathrm{C}$ - by three days.

There is a growing evidence that a number of fish species in different regions may respond to climate change by shifting their distributions to areas with more favorable conditions or by changes in productivity in response to the new conditions (Sabates, Martin, Lloret, \& Raya, 2006; Hsieh, Kim, Watson, Di Lorenzo, \& Sugihara, 2009; Rijnsdorp, Peck, Engelhard, Möllmann, \& Pinnegar, 2009; Auth et al., 2017; Kleisner et al., 2017). The sea water temperature in November 2017 on the shelf of the Crimean Peninsula varied from $12.5^{\circ}$ to $14.8^{\circ} \mathrm{C}$, which contributed not only to the acceleration of embryonic and post-embryonic development of sprat, but also to the enrichment of the larval fodder base (Finenko, Anninsky, \& Datzyk, 2018; Klimova et al., 2018).

Considering the possible reasons for the mass spawning of sprats in November 2017 in the Northern sector of the Black sea, it may not be excluded that there may have been latitudinal shifts in the distribution of the southern population of sprat, whose mass spawning off the Turkish coast is usually observed in November (Klimova et al., 2014). The fundamental importance of combined effects of fishing pressure and climate change on distribution patterns of commercially exploited fish were reported for the North Sea, Australia, California, Iceland and Norway (Holst, Dragesund, Hamre, Misund, \& Østvedt, 2002, Hsieh, Reiss, Hewitt, \& Sugihara, 2008, Last et al., 2011, Engelhard, Righton, \& Pinnegar, 2013). The decrease in commercial stocks of sprat off the Crimean Peninsula in 2017 as a result of its intensive fisheries in 2015-2016 (Shlyakhov et al., 2018) and water temperature increase in the layer $0-100 \mathrm{~m}$ could have had a positive impact on the abundance of fodder zooplankton in this area (Belokopytov, 2017, Finenko et al., 2018; Klimova et al., 2018) that might have resulted in migration of southern populations of sprat from the 
coast of Turkey along the Eastern shelf of the Black sea to the shelf of the Crimean Peninsula.

Currently, regional studies of changes in the spawning phenology of mass short-cycle fish are of great interest in terms of the certain species response to climate warming (Asch, 2015, Auth et al., 2017, Edwards \& Richardson, 2004, Genner et al., 2010, Koslow, Goericke, \& Watson, 2013). For the reason of the recently observed extension of the mass spawning period of temperate-water fish species to the autumn hydrological season, it is interesting to consider the effectiveness of their spawning during the spring "offseason". ". The research, carried out during the expedition cruises in 2016, 2017 and 2019 provided the new data for studying and analyzing the state of the ichthyoplankton complexes in the spring hydrological season in shelf and deep waters of the Black sea off the Crimean peninsula and coast of the Caucasus.

\section{Materials and Methods}

Ichthyoplankton samples were collected in shelf and deepwater regions of the Black sea off the Crimean Peninsula in April 2016 (latitude 44 $19^{\prime}-45^{\circ} 42^{\prime} \mathrm{N}$, longitude $32^{\circ} 26^{\prime}-36^{\circ} 26^{\prime} \mathrm{E}$ ), in March-April 2017 (latitude $43^{\circ} 21^{\prime}-45^{\circ} 50^{\prime} \mathrm{N}$, longitude $31^{\circ} 37^{\prime}-36^{\circ} 55^{\prime} \mathrm{E}$ ),

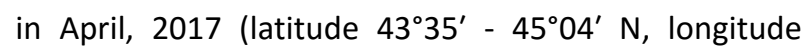
$31^{\circ} 32^{\prime}-36^{\circ} 24^{\prime} \mathrm{E}$ ), in April-May, 2019 (latitude 42 $32^{\prime}$ $45^{\circ} 04^{\prime} \mathrm{N}$, longitude $31^{\circ} 32^{\prime}-39^{\circ} 48^{\prime} \mathrm{E}$ ) in the $84^{\text {th }}, 93$ th, $94^{\text {th }}$ and $106^{\text {th }}$ cruises of R/V "Professor Vodyanitsky" respectively. Samples were collected using a BR-80/113 type plankton net ( $80 \mathrm{~cm}$ diameter, $400 \mu \mathrm{m}$ mesh size) in vertical fishing mode from the sea floor to the surface in the shallow water regions and from the lower oxygen zone to the sea surface in deepwater regions. Samples were preserved in $4 \%$ formalin seawater solution at sea and returned to the laboratory for sorting with a binocular MBS-9. Fish eggs and larvae were counted, measured and identified to the lowest taxonomic level possible based on Russell (1976), Dekhnik (1973), D'Ancona (1933). A total of 213 ichthyoplankton samples were studied.

The study of the fish larvae nutrition was carried out according to the method Duka \& Sinyukova (1976). According to Gorbunova (1958), Dekhnik (1973) sprat larvae were divided into two size groups: total length (TL, mm) up to $5.9 \mathrm{~mm}$ - the younger age group (I-II), which included larvae on the yolk and mixed types of nutrition and larvae TL more than $6 \mathrm{~mm}$ - the older age group (III), which included larvae transited to the exogenous type of nutrition. A total of 462 sprat larvae was studied sized 1.9 to $23.0 \mathrm{~mm}$.

Table 1. Species composition and mean number (ind./ $\mathrm{m}^{2}$ ) of the Black sea ichthyoplankton in the spring season of 2016, 2017 and 2019

\begin{tabular}{|c|c|c|c|c|}
\hline \multirow{3}{*}{ Species composition } & \multicolumn{4}{|c|}{ Dates of sampling } \\
\hline & $\begin{array}{c}19.04 .^{-} \\
25.04 . \\
2016\end{array}$ & $\begin{array}{c}28.03-13.04 \\
2017\end{array}$ & $\begin{array}{c}22.04-06.05 \\
2017\end{array}$ & $\begin{array}{c}20.04-11.05 \\
2019\end{array}$ \\
\hline & $\frac{\text { Eggs }}{\text { Larvae }}$ & $\frac{\text { Eggs }}{\text { Larvae }}$ & $\frac{\text { Eggs }}{\text { Larvae }}$ & $\frac{\text { Eggs }}{\text { Larvae }}$ \\
\hline Family: Clupeidae & 10,0 & 20,0 & 12,16 & 3,77 \\
\hline Sprattus sprattus (Linnaeus, 1758) & $\overline{2,19}$ & $\overline{1,5}$ & $\overline{13,79}$ & $\overline{0,74}$ \\
\hline Family: Gadidae & $\underline{4,09}$ & $\underline{0,9}$ & $\underline{1,11}$ & $\underline{0,07}$ \\
\hline Merlangius merlangus Linnaeus, 1758 & $\overline{0,66}$ & $\overline{0}$ & $\overline{0}$ & $\overline{0}$ \\
\hline Gadidae sp & & $\underline{0}$ & $\frac{0}{0,29}$ & $\frac{0}{0,04}$ \\
\hline Family: Lotidae & $\underline{0}$ & & & $\underline{0}$ \\
\hline Gaidropsarus mediterraneus (Linnaeus, 1758) & $0, \overline{19}$ & & & 0,02 \\
\hline Family: Syngnathidae & & & $\underline{0}$ & $\underline{0}$ \\
\hline Syngnathus schmidti (Popov, 1927) & & & 0,03 & 0,02 \\
\hline Family: Blenniidae & & & & $\underline{0}$ \\
\hline Parablennius tentacularis (Brünnich, 1768) & & & & 0,02 \\
\hline Family: Gobiidae & $\underline{0}$ & $\underline{0}$ & $\underline{0}$ & $\underline{0}$ \\
\hline Pomatoschistus minutus (Pallas, 1770) & $0, \overline{5} 7$ & $\overline{0,1}$ & $0, \overline{0} 6$ & $0, \overline{10}$ \\
\hline Gobius niger Linnaeus, 1758 & & & & $\frac{0}{0,05}$ \\
\hline Family: Labridae & $\underline{0,38}$ & & & \\
\hline Ctenolabrus rupestris (Linnaeus, 1758) & $\overline{0}$ & & & \\
\hline & $\underline{1,71}$ & & $\underline{0,43}$ & $\underline{0,22}$ \\
\hline $\begin{array}{l}\text { Family Scophthalmidae: } \\
\text { Scophthalmus maeoticus (Pallas, 1814) }\end{array}$ & 0 & & 0 & 0 \\
\hline Total, ind./m² & $\underline{16,18}$ & $\underline{20,9}$ & $\underline{13,70}$ & $\underline{4,06}$ \\
\hline & $\overline{3.61}$ & $\overline{1,7}$ & $\overline{14,17}$ & $\overline{0,99}$ \\
\hline Standard deviation & $\underline{23,95}$ & $\underline{41,56}$ & $\underline{29,45}$ & 5,77 \\
\hline & $\overline{6,39}$ & $\overline{3,03}$ & $\overline{18,85}$ & $\overline{2,32}$ \\
\hline Number of samples & 25 & 47 & 59 & 82 \\
\hline Mean sea surface temperature, ${ }^{\circ} \mathrm{C}$ & 11,2 & 9,2 & 11,5 & 12,7 \\
\hline Standard deviation & 0,67 & 0,79 & 2,08 & 2,37 \\
\hline
\end{tabular}


Dynamics of monthly mean sea surface temperature was calculated using daily maps of sea surface temperature for the period 1982-2017 with a spatial resolution hbcof $0.0417^{\circ}$ retrieved from CMEMS website http://marine.copernicus.eu/ for the region $44^{\circ} 50-45^{\circ} 00 \mathrm{~N}$ and $32^{\circ} 70-33^{\circ} 70 \mathrm{E}$. The data are interpolated into nodes regular mesh and have a 4th processing level (Level 4).

\section{Results and Discussions}

In ichthyoplankton samples collected in the spring season of 2016, 2017 and 2019 on the shelf and in the deepwater areas of the Black sea, eggs and larvae of 10 fish species from 9 families were detected. Eggs and larvae of temperate-water species Sprattus sprattus dominated. The average number of eggs ranged from 4.06 to 20.9 ind./m², and larvae - from 0.99 to 14.17 ind./ $\mathrm{m}^{2}$ (Table 1, Figure 1).
From April 19 to April 25, 2016, the species composition of ichthyoplankton was represented by 6 species characteristic of the beginning of the spring season (Klimova, Ignat'ev, Vdodovich, \& Gubanov, 2016). The average abundance of eggs in a sample was $16.18 \mathrm{ind} . / \mathrm{m}^{2}$, and the larvae $3.61 \mathrm{ind} . / \mathrm{m}^{2}$ (Table 1). Thermophilic species (Ctenolabrus rupestris and Pomatoschistus minutus) were detected only in samples collected in western sector of investigation: on the beam of Sevastopol, in the Karkinitsky and Kalamitsky bays (Table 1; Figure 1). Eggs and larvae of S. sprattus dominated in samples comprising 62 and $61 \%$ respectively. The maximum number of eggs was 66 , and the larvae $14 \mathrm{ind} . / \mathrm{m}^{2}$. The proportion of dead sprat eggs was $87.6 \%$, Scophthalmus maeoticus $88.9 \%$, and the eggs of Merlangius merlangus and $C$. rupestris were all dead. The greatest mortality of fish eggs was registered at shallow stations in the Karkinitsky and Kalamitsky bays and coastal stations of the Laspi Bay.

Table 2. The results of trophological studies

\begin{tabular}{lcccc}
\hline & \multicolumn{3}{c}{ Dates of sampling } \\
\cline { 2 - 5 } \multicolumn{1}{c}{ Values } & $\begin{array}{c}19.04 .-25.04 \\
2016\end{array}$ & $\begin{array}{c}28.03-13.04 . \\
2017\end{array}$ & $\begin{array}{c}22.04-06.05 . \\
2017\end{array}$ & $\begin{array}{c}20.04-11.05 . \\
2019\end{array}$ \\
\hline $\begin{array}{l}\text { Larvae TL, mm: min.-max. } \\
\text { Average }\end{array}$ & $\frac{4,1-20}{11}$ & $\frac{2,5-17,8}{7}$ & $\frac{2,5-23}{7}$ & $\frac{1,9-21}{8}$ \\
Number of copepod consumed, ind. & $1-4$ & $1-3$ & $1-21$ & $1-2$ \\
Length of copepod consumed, $\mathrm{mm}$ & $0,1-0,9$ & $0,15-0,275$ & $0,15-0,925$ & $0,15-0,35$ \\
$\begin{array}{l}\text { The proportion of larvae } \\
\text { (TL }>4,3 \mathrm{~mm} \text { ) with food in guts, } \%\end{array}$ & 26 & 41 & 25 & 33 \\
\hline
\end{tabular}

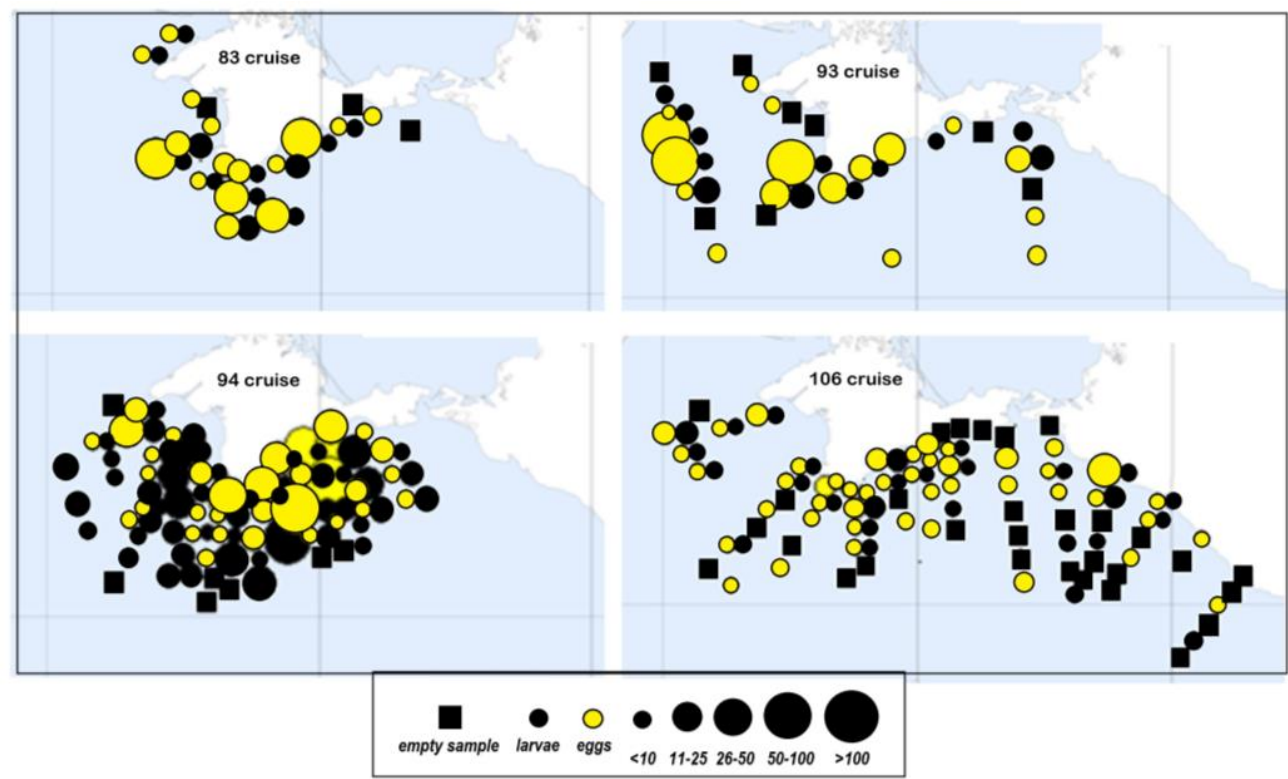

Figure 1. Schematic maps of the spatial distribution of fish eggs and larvae (ind./ $\mathrm{m}^{2}$ ) in the $84^{\text {th }}, 93^{\text {rd }}, 94^{\text {th }}$ and $106^{\text {th }}$ cruises of the $\mathrm{R} / \mathrm{V}$ "Professor Vodyanitsky” 


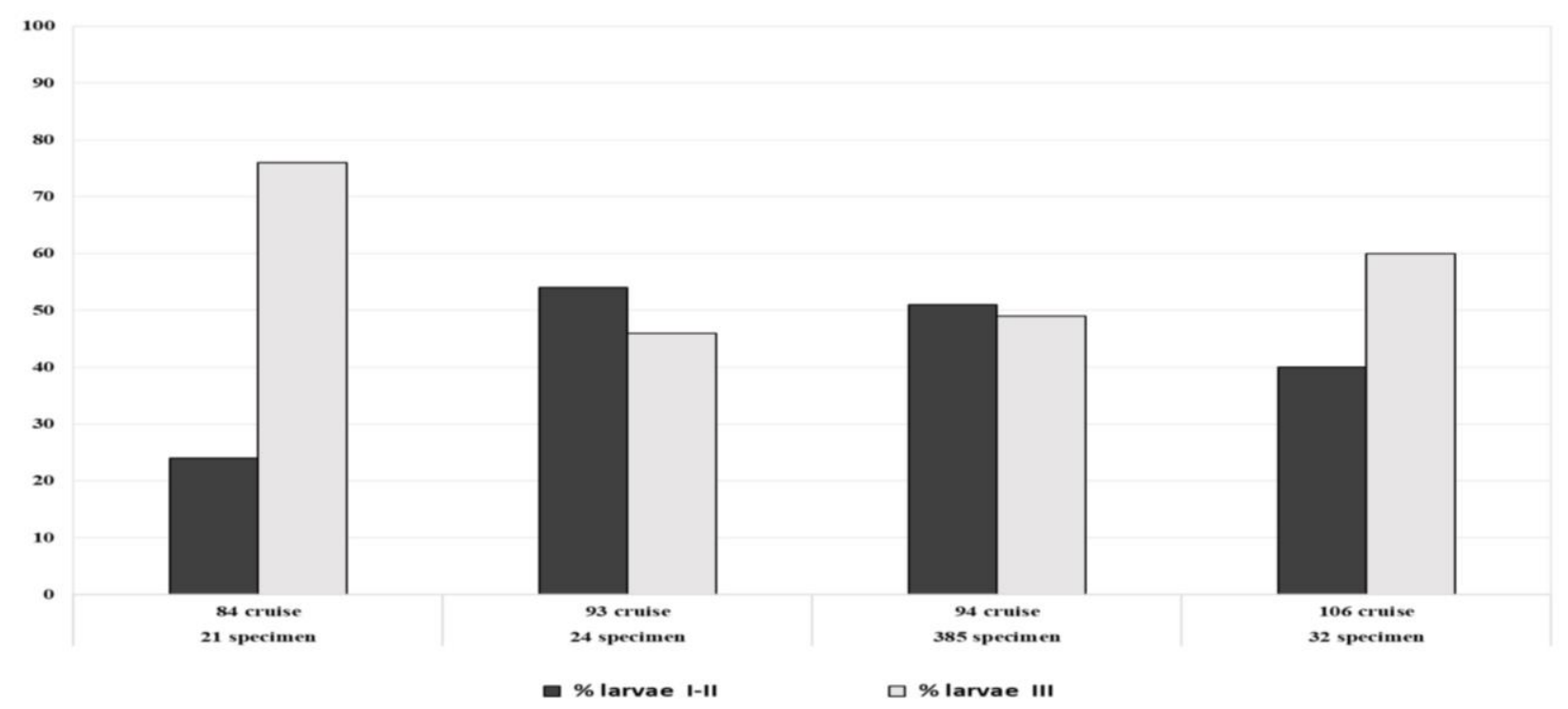

Figure 2. The proportion of Sprattus sprattus larvae on yolk and mixed types of nutrition (I-II) and exogenous type of nutrition (III) in the $84^{\text {th }}, 93^{\text {rd }}, 94^{\text {th }}$ and $106^{\text {th }}$ cruises of the R / V "Professor Vodyanitsky"

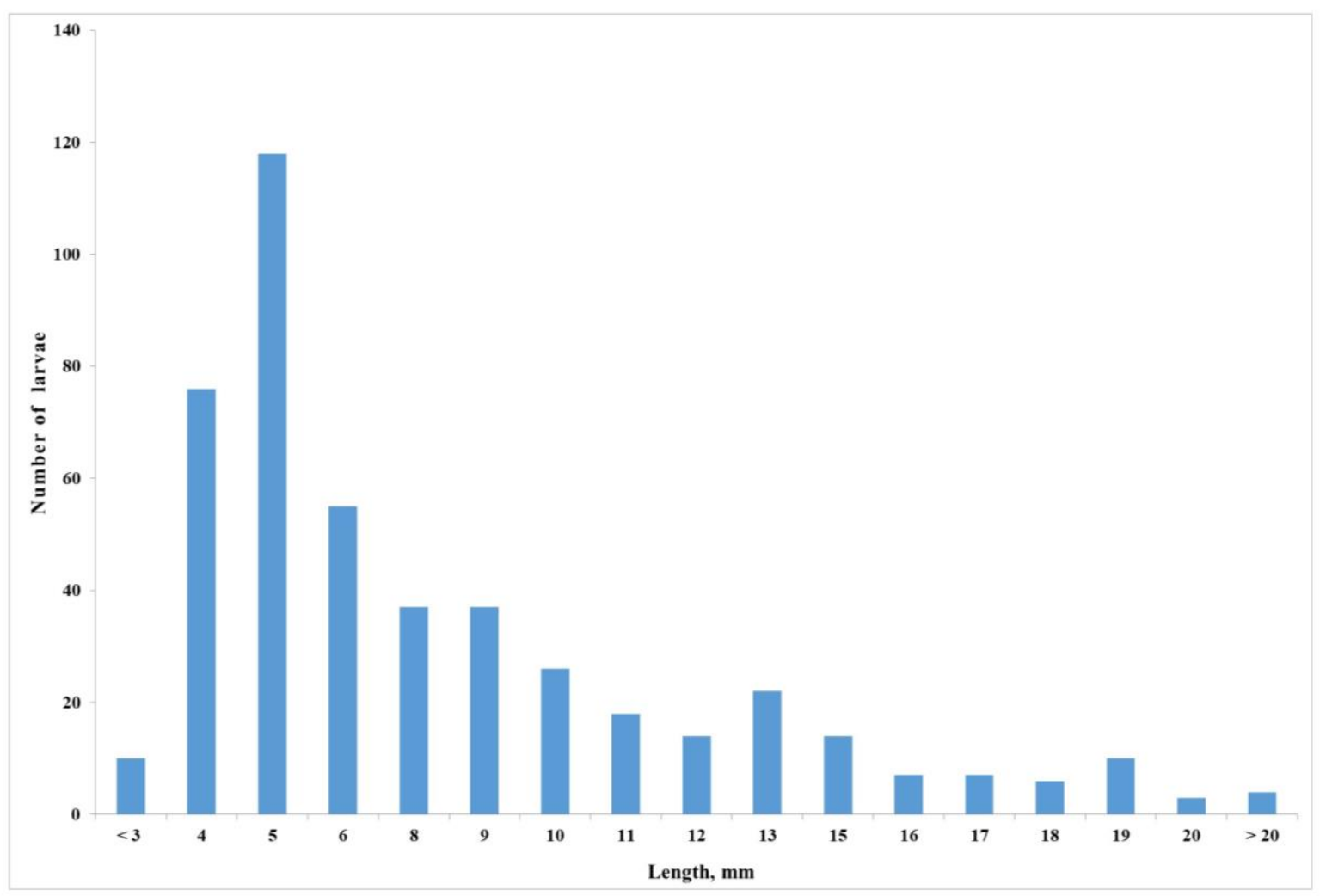

Figure 3. Size-frequency distribution of the variational series of sprat larvae lengths in spring research cruises of 2016, 2017 and 2019. 
The nutrition patterns are studied and presented for sprat larvae, as the most prevailing in ichthyoplankton (Table 2). In the samples collected from April 19 to 25, 2016, the older age group of sprat larvae prevailed, the proportion of larvae of the younger age group (mean length $5 \mathrm{~mm}$ ) was $24 \%$ (Figure 2).

In 2017, ichthyoplankton was collected from March 28 to April 13 and from April 22 to May 6. In samples collected in March-April, only 4 species of fish eggs and larvae were detected on the beam of the Crimean peninsula (Table 1, Figure 1). The average number of eggs was 20.9 , and the larvae -1.7 ind. $/ \mathrm{m}^{2}$. Eggs (95.7\%) and larvae (88.2\%) of sprat were dominant; their maximum abundance was 224 and 20 ind./ $\mathrm{m}^{2}$, respectively. The high abundance of sprat eggs and larvae, as well as the predominance of larvae of the younger age group in the samples, indicated an intensive spawning of sprat. Thermophilic species were observed only in the western sector of research: on the beam of Sevastopol, in the Karkinitsky and Kalamitsky bays.

In samples collected from the last decade of April to the 6th of May ichthyoplankton off the Crimean peninsula was represented by 6 fish species. Eggs and larvae of thermophilic fish species in ichthyoplankton were detected only in the western sector of research, where the temperature of the water surface in the sea reached $14^{\circ} \mathrm{C}$ and therefore was favorable for the start of their spawning. (Table 1, Figure 1). The average number of eggs was 13.7 , and the larvae $-14.17 \mathrm{ind} . / \mathrm{m}^{2}$. Along the coast of Crimea from the Kerch Peninsula to the Cape Sarych, the water temperature was $8.4-8.5^{\circ} \mathrm{C}$ (Artamonov et al., 2019) and therefore was favorable for spawning of temperate-water species $S$. sprattus. The maximum number of sprat eggs was 162.8 ind. $/ \mathrm{m}^{2}$, and the larvae -116 ind. $/ \mathrm{m}^{2}$. Thus the maximum number of sprat larvae four times exceeded that at the peak of the sprat spawning season in December-January 1958-1959 (Dekhnik, 1973).

The high abundance of wide size range sprat larvae $(2.5-23.0 \mathrm{~mm})$ with the prevalence of younger age groups in the spring season of 2017 evidenced the massive effective spawning of $S$. sprattus and a favorable food supply for the survival of its larvae (Figure 2).

From April 20 to May 11, 2019 the average surface water temperature in the sea was $12.7^{\circ} \mathrm{C}$. At the beginning of the survey the temperature was about $9^{\circ} \mathrm{C}$ and by the end of the sampling, it already exceeded $15^{\circ} \mathrm{C}$, which was the highest value comparing to sea surface temperatures in previous studies (Table 1 ). In the samples, 9 species of fish eggs and larvae from 7 families were identified. The average number of eggs and larvae was 4.06 and 0.99 ind. $/ \mathrm{m}^{2}$, respectively. Moderate-water fish species were represented by eggs and larvae of S. sprattus, eggs of $M$. merlangus, Gadidae sp. larvae and juvenile Gaidropsarus mediterraneus; thermophilic species were represented by eggs of spring spawning $S$. maeoticus, larvae of Parablennius tentacularis, 2 species of gobies and Syngnathus schmidti (Table 1). The larvae of thermophilic species amounted to $19.2 \%$ in total. Eggs (93\%) and larvae $(74.7 \%)$ of moderate-water S. sprattus dominated in samples.

The maximum number of sprat eggs and larvae was an order of magnitude lower than in the spring of 2017. A decrease in the number of sprat eggs and larvae, as well as the predominance of older age group larvae in samples are known to be markers of the finishing of the spawning season. However, the proportion of larvae of the younger age group in 2019 was still quite significant and amounted to $40 \%$. The minimum size of the larvae of the younger age group was only $1.9 \mathrm{~mm}$, and their average length (LT) was $3.65 \mathrm{~mm}$. A reduction of a hatching larvae size is typical under increasing water temperature conditions during embryonic and postembryonic development (Petereit, 2009).

The latest data on ichthyoplankton studies in the spring hydrological season in this research area were obtained in March 1986 (Tkach, et al., 1991). Ichthyoplankton was represented by eggs and larvae of S. sprattus and $M$. merlangus. Sprat had already completed its winter spawning season. The average number of its eggs did not exceed 1.9 ind. $/ \mathrm{m}^{2}$, and the larvae -4.4 ind. $/ \mathrm{m}^{2}$, and the maximum number of eggs and larva were 20 and 26 ind./ $/ \mathrm{m}^{2}$ respectively. Only 5\% of 360 larvae collected in vertical and horizontal catches were less than $10 \mathrm{~mm}$ in size (Tkach, et al., 1991).

The data on the size range of sprat larvae obtained in spring 2016, 2017 and 2019 differed significantly from those in March-April 1986. A high proportion of sprat larvae of a younger age group (up to $6 \mathrm{~mm} \mathrm{TL}$ ) was observed in all ichthyoplankton samples, indicating the continuation of its effective spawning (Figure 3 ).

The positive temperature anomalies are known to contribute to improving the food supply of fish larvae and consequently affect the recruitment success of natural fish populations (Fromentin \& Planque, 1996). And contrary, under adverse hydrological conditions, the development of fodder zooplankton may be delayed, the species composition or the size of prey can change, and according to the match/mismatch hypothesis, cause mortality of the larvae when transiting from yolk to exogenous nutrition (Dekhnik et al., 1970; O'Connell \& Raymond, 1970; Cushing, 1990; Fuiman \& Werner, 2002). Compared to 1986, in our studies the proportion of larvae with food objects in the guts increased, indirectly indicating a favorable food supply for fish larvae. In samples, collected in research cruises in spring 2016, 2017, 2019, the larvae of the younger age group sized from 4 to $6 \mathrm{~mm}$ prevailed in total. It could have indicated the match between the maximum development of the consumed forms and larvae hatching and development, as the larvae at the stage of transition to active exogenous nutrition appeared to have been provided with a sufficient food supply, which contributed to a greater possibility of their survival. 


\section{Conclusions}

Climate warming induced changes in the hydrological regime of the Black sea favorably affect the spawning activity of the sprat, resulting in the extension of the terms of its mass productive spawning for the autumn and spring hydrological seasons. The fact of the mass productive spawning of sprat in the spring season of 2016, 2017 and 2019 is confirmed by the high number of sprat eggs and larvae (the maximum number of eggs reached 224 ind. $/ \mathrm{m}^{2}$, and larvae- 116 ind. $/ \mathrm{m}^{2}$ ), and by the prevalence of larvae of the younger age group in the ichthyoplankton samples as well.

The reduction in the age and size-weight composition of sprat in the Black sea, which has been observed since 2016 as a result of an increase in its commercial fishing on the shelf of the Crimean Peninsula, did not affect its spawning activity. We believe this to be derived from the wide range of the sprat's habitat distribution area (both the shelf and deep-water areas of the entire Black sea), its early puberty (at age of 10 months) and multiportion spawning. Different age sprat individuals are able to begin spawning simultaneously under favorable temperature conditions due to year-round reproduction of sprat in the Black sea.

\section{Ethic statement}

Specific permission was not required to conduct sampling for this research. No experiments have been carried out using living organisms. The authors confirm that the field studies did not involve any endangered or protected species.

\section{Funding Information}

This work was carried out within the framework of government research assignment of A.O.Kovalevsky Institute of Biology of the Southern Seas of RAS "Regularities in the formation and anthropogenic transformation and development of bioresources in the Azov-Black Sea basin and other regions of the World Ocean", №AAAA-A18-118020890074-2 and supported by grants from Russian Foundation for Basic Research №18-44-920007 "The role of global and local factors in the formation of ichthyoplankton communities of the Black Sea" and "The response of the Black Sea pelagic ecosystem to climate change in the region (by the examples of jellyfish, ctenophores and small pelagic fish)" №18-44-920022.

\section{Author Contributions}

Klimova T. contributed substantially to the conception and design of the study. Klimova T., Vdodovich I. and Podrezova P. studied ichthyoplankton samples, worked on the analysis and interpretation of the data, wrote and reviewed the manuscript.
Identification of ichthyoplankton was made by Klimova T. and Podrezova P., larval fish nutrition was studied by Vdodovich I.

\section{Conflict of Interest}

The authors declare that they have no known competing financial interests or personal relationships that could have appeared to influence the work reported in this paper. All listed co-authors declare that the present study was conducted in an ethical, professional and responsible manner.

\section{Acknowledgements.}

We would like to thank the reviewers for the evaluation of the manuscript and useful comments.

\section{References}

Aleev, Yu.G. (1958). O biologii i hozyajstvennom znachenii chernomorskogo shprota Sprattus sprattus phalericus (Risso). Proceedings of the Sevastopol biological station, 10, 97-107 (in Russian).

Artamonov, Yu.V., Fedirko, A.V., Skripaleva, E.A., Shutov, S.A., Deryushkin, D.V., Kolmak, R.V., ... Shcherbachenko, S.V. (2019). Water structure in the area of the Rim Black Sea current in spring and summer 2017 (94th, 95th cruises of the R/V "Professor Vodyanitsky"). Ecological safety of coastal and shelf zones of sea, 1, 16-28. http://dx.doi.org/10.22449/2413-5577-2019-1-16-28.

Asch, R.G. (2015). Climate change and shifts in larval fish phenology. Proceedings of the National Academy of Sciences of the USA, 112 (30), E4065-E4074. https://doi.org/10.1073/pnas.1421946112

Auth, T.D., Daly, E.A., Brodeur, R.D., \& Fisher, J.L. (2017). Phenological and distributional shifts in ichthyoplankton associated with recent warming in the northeast Pacific Ocean. Global Change Biology, 24 (11), 259-272. https://doi.org/10.1111/gcb.13872

Belokopytov, V.N. (2017). Klimaticheskie izmenenija gidrologicheskogo rezhima Chernogo morja (PhD Thesis). Sevastopol, RF. (in Russian).

Brierley, A.S., \& Kingsford, M.J. (2009). Impacts of climate change on marine organisms and ecosystems. Current Biology, 19, R602-R614.

https://doi.org/10.1016/j.cub.2009.05.046

Chen, I.-C., Hill, J.K., Ohlemüller, R., Roy, D.B., \& Thomas, C.D. (2011). Rapid range shifts of species associated with high levels of climate warming. Science, 333 (6045), 10241026. https://doi.org/10.1126/science.1206432

Cushing, D.H. (1995). Population Production and Regulation in the Sea: a Fisheries Perspective. London, Cambridge University Press, $354 \mathrm{pp}$.

Cushing, D.H. (1990). Plankton production and year-class strength in fish populations: an update of the match/mismatch hypothesis. Advances in Marine Biology, 26, 249-292. https://doi.org/10.1016/S00652881(08)60202-3

D’Ancona, U. (1933). Uova, larve e stadigiovanili di Teleostei. Fauna e Flora del Goifo di Napoli, 38. Monography: p.2. (pp. 182-255).

Dekhnik, T.V., Duka, L.A., Kalinina, E.M., Oven, L.S., Salekhova, 
L.P., \& Sinyukova, V. I. (1970). Reproduction and ecology of abundant fish in the Black Sea in the early stages of ontogenesis (Razmnozhenie i ekologiya massovyh ryb Chernogo morya na rannih stadiyah ontogeneza). Kiev, Naukova Dumka, 204 pp. (in Russian)

Dekhnik, T.V. (1973). Ichthyoplankton of the Black Sea. Kiev, Naukova dumka, $234 \mathrm{pp}$. (in Russian)

Doney, S.C., Ruckelshaus, M., Duffy, J.E., Barry, J.P, Chan, F., English, C.A., ... Talley, L.D. (2012). Climate change impacts on marine ecosystems. Annual Review of Marine Science, 4, 11-37.

https://doi.org/10.1146/annurev-marine-041911111611

Duka, L.A., \& Sinyukova, V.I. (1976). A manual for the study of the nutrition of marine fishes larvae and juveniles under natural and experimental conditions. Kiev, Naukova dumka, 110 pp. (in Russian)

Edwards, M., \& Richardson, A.J. (2004). Impact of climate change on marine pelagic phenology and trophic mismatch. Nature, 430(7002), 881-884. https://doi.org/10.1038/nature02808

Engelhard, G.H., Righton, D.A., \& Pinnegar, J.K. (2013). Climate change and fishing: a century of shifting distribution in North Sea cod. Global change biology, 20(8), 2473-2483. https://doi.org/10.1111/gcb.12513

Fincham, J.I., Rijnsdorp, A.D., \& Engelhard, G.H. (2013). Shifts in the timing of spawning in sole linked to warming sea temperatures. Journal of Sea Research, 75, 69-76. https://doi.org/10.1016/j.seares.2012.07.004

Finenko, G.A., Anninsky, B.E., \& Datzyk, N.A. (2018). Trophic characteristics of Mnemiopsis Leidyi and its impact on the plankton community in Black sea coastal waters. Oceanology, 58(6), 817-824. https://doi.org/10.1134/S0001437018060048

Fromentin, J.-M., \& Planque, B. (1996). Calanus and environment in the eastern North Atlantic. Influence of the North Atlantic Oscillation on C. finmarchius and C. helgolandicus. Marine Ecology Progress Series, 134, 111118. http://doi.org/10.3354/meps134111

Fuiman, L.A, \& Werner, R.G. (2002). Fishery science: the unique contributions of early life stages. Blackwell science, Oxford, $337 \mathrm{pp}$.

Genner, M.J., Halliday, N.C., Simpson, S.D., Southward, A.J., Hawkins S.J., \& Sims, D.W. (2010). Temperature-driven phenological changes within a marine larval fish assemblage. Journal of Plankton Research, 32(5), 699708. https://doi.org/10.1093/plankt/fbp082

Giragosov, V.E., Zuev, G.V., \& Repetin, L.N. (2006). Variability of reproductive potential of the Black Sea sprat (Sprattus sprattus phalericus) in connection with temperature environmental conditions. Marine Ecological Journal, 5(4), 5-22. (in Russian)

Gorbunova, N.N. (1958). Reproduction and development of European sprat Sprattus sprattus phalericus (Risso). Proceedings of the Sevastopol biological station, 10, 108-125. (in Russian)

Hewitson, B., Jenetos A.C., Carter, T.R., Giorgi, F., Jones, R.G., Kwon, W.-T., ... van Aalst M. (2014). Regional context. In: Climate Change 2014: Impacts, Adaptation, and Vulnerability. Part B: Regional Aspects. Contribution of Working Group II to the Fifth Assessment Report of the Intergovernmental Panel on Climate Change. [V.R. Barros, C.B. Field, D.J. Dokken, M.D. Mastrandrea, K.J. Mach, T.E. Bilir, M. Chatterjee, K.L. Ebi, Y.O. Estrada, R.C. Genova, B. Girma, E.S. Kissel, A.N. Levy, S. MacCracken,
P.R. Mastrandrea \& L.L. White (eds.)]. (pp.1136-1182). Cambridge, United Kingdom and New York, NY, USA, Cambridge University Press.

Hoegh-Guldberg, O., \& Bruno, J.F. (2010). The impact of climate change on the World's marine ecosystems. Science, 328(5985), 1523-1528. http://doi.org/10.1126/science.1189930

Holst, J.C., Dragesund, O., Hamre, J., Misund, O.A., \& Østvedt, O.J. (2002). Fifty years of herring migrations in the Norwegian Sea. ICES Marine Science Symposia, 215, 352- 360.

Hsieh, C.H., Reiss, C.S., Hewitt, R.P., \& Sugihara, G. (2008). Spatial analysis shows that fishing enhances the climatic sensitivity of marine fishes. Canadian Journal of Fisheries and Aquatic Sciences, 65, 947- 961. https://doi.org/10.1139/f08-017

Hsieh, Ch., Kim, H.J., Watson, W., Di Lorenzo, E., \& Sugihara, G. (2009). Climate-driven changes in abundance and distribution of larvae of oceanic fishes in the southern California region. Global change biology, 15(9), 21372152. https://doi.org/10.1111/j.1365-2486.2009.01875.x

Ivanov, L.S., Kostyuchenko, V.A., \& Kautish, I. (1979). The main biological features of commercial fish. Patterns of growth. In V.N. Greze (Ed.), Fundamentals of biological productivity of the Black Sea (pp. 253-259). Kiev, Naukova Dumka, 392 pp.

Jansen, T., \& Gislason, H. (2011). Temperature affects the timing of spawning and migration of North Sea mackerel. Continental Shelf Research, 31, 64-72.

Kleisner, K.M., Fogarty, M.J., McGee, S., Hare, J.A., Moret, S., Perretti, Ch.T., \& Saba, V.S. (2017). Marine species distribution shifts on the U.S. Northeast Continental Shelf under continued ocean warming. Progress in Oceanography, 153, 24-36.

https://doi.org/10.1016/j.pocean.2017.04.001

Klimova, T.N., \& Podrezova, P.S. (2018). Seasonal distribution of the Black Sea ichthyoplankton near the Crimean Peninsula. Regional studies in Marine Science, 24, 260269. https://doi.org/10.1016/j.rsma.2018.08.013

Klimova, T.N., Vdodovich, I.V., \& Anninskyi, B.E. (2010). Ichthyoplankton in the Plankton Community of the Western Sector of the Black Sea in October 2005. Journal of Ichthyology, 50(4), 314-320. https://doi.org/10.1134/S0032945210040041

Klimova, T.N., Vdodovich, I.V., Finenko, G.A., Satilmis, H.H., Bat, L., Ustum, F., ... Birinci-Ozdemir, Z. (2014). Ichthyoplankton of the coastal waters of the SouthWestern part of the Crimea and Sinop Peninsula in 2002 - 2003.ğ Marine ecological journal, 13(3), 33-42.

Klimova, T.N., Subbotin, A.A., Melnikov, V.V., Serebrennikov, A.N., \& Podrezova, P.S. (2019). Spatial distribution of ichthyoplankton near the Crimean Peninsula in the summer spawning season 2013. Marine biological journal, 4(1), 63-80. http://doi: 10.21072/mbj.2019.04.1.06

Klimova, T.N., Anninskyi, B.E Vdodovich, I.V., \& Podrezova, P.S. (2018). Osobennosti vidovogo sostava i prostranstvennogo raspredeleniya ihtio- i zheletelogo makroplanktona Chernogo morya u Krymskogo poluostrova v noyabre 2017. Scientific journal Eurasian Union of Scientists, 4-3(49), 7-11. (in Russian)

Klimova, T.N., Ignat'ev, S.M., Vdodovich, I.V., \& Gubanov, V.V. (2016). Sostoyanie intio- i makroplanktonnogo kompleksov na shel'fe Krymskogo poluostrova v aprele 
2016. Proceedings of International Scientific and Technical Conference "Environmental control systems2016" (p.159). Sevastopol. (in Russian)

Koslow, J.A., Goericke, R., \& Watson, W. (2013). Fish assemblages in the Southern California Current: Relationships with climate, 1951-2008. Fish Oceanography, 22(3), 207-219. https://doi.org/10.1111/fog.12018

Kröncke, I., Reiss, H., Eggleton, J.D., Aldridge, J., Bergman, M.J.N., Cochrane, S., ... Rees, H.L. (2011). Changes in North Sea macrofauna communities and species distribution between 1986 and 2000. Estuarine, Coastal and Shelf Science, 94(1), 1-15. https://doi.org/10.1016/j.ecss.2011.04.008

Lasker, R. (1964). An experimental study of the effect of temperature on the incubation time, and growth of Pacific sardine embryos and larvae. Copeia, 2, 399-405. http:// doi.org/10.2307/1441033

Last, P.R., White, W.T., Gledhill, D., Hobday, A.J., Brown, R., Edgar, G.J., \& Pecl, G.T. (2011). Long-term shifts in abundance and distribution of a temperate fish fauna: a response to climate change and fishing practices. Global Ecology and Biogeography, 20, 58- 72. https://doi.org/10.1111/j.1466-8238.2010.00575.x

McQueen, K., \& Marshall, T.C. (2017). Shifts in spawning phenology of cod linked to rising sea temperatures. ICES Journal of Marine Science, 74(6), 1561-1573. https://doi.org/10.1093/icesjms/fsx025

Monastyrsky, G.N. (1958). The dynamics of the number of commercial fish. Proceedings of VNIRO, 21, 3-163. (in Russian).

O'Connell, C.P., \& Raymond, L.P. (1970). The effect of food density on survival and growth of early post yolk-sac larvae of the northern anchovy (Engraulis mordax Girard) in the laboratory. Journal of Experimental Marine Biology and Ecology, 5(2), 187-197. https://doi.org/10.1016/0022-0981(70)90017-1

Oguz, T., Cokacar, T., Malanotte-Rizzoli, P., \& Ducklow, H. W. (2003). Climatic Warming and Accompanying Changes in the Ecological Regime of the Black Sea during the 1990s. Global Biogeochemical Cycles, 17(3), 1088. https://doi.org/10.1029/2003GB002031

Ottersen, G, Hjermann, D. $\varnothing$., \& Stenseth, N.C. (2006). Changes in spawning stock structure strengthen the link between climate and recruitment in a heavily fished cod (Gadus morhua) stock. Fisheries Oceanography, 15, 230-243. https://doi.org/10.1111/j.1365-2419.2006.00404.x

Oven, L.S. (1979). The main biological features of commercial fish. Reproduction. In V.N. Greze (Ed.), Fundamentals of biological productivity of the Black Sea (pp. 242-253). Kiev, Naukova Dumka, 392 pp. (in Russian)

Parmesan, C., \& Yohe, G. (2003). A globally coherent fingerprint of climate change impacts across natural systems. Nature, 421, 37-42 . ttps://doi.org/10.1038/nature01286

Perry, A.L., Low, P.J., Ellis, J.R., \& Reynolds, J.D. (2005). Climate change and distribution shifts in marine fishes. Science, 308(5730), 1912-1915.

http://doi.org/10.1126/science.1111322
Petereit, Ch. (2009) Influence of temperature and salinity on sprat (Sprattus sprattus L.) eggs and yolk sac larvae from contrasting environments. (PhD/Doctoral thesis), Christian-Albrechts-Universität, Kiel, Germany. Retrieved from http://oceanrep.geomar. de/id/eprint/7810

Rijnsdorp, A.D., Peck, M.A., Engelhard, G.H., Möllmann, Ch., \& Pinnegar, J.K. (2009). Resolving the effect of climate change on fish populations. ICES Journal of Marine Science, 66(97), 1570-1583. https://doi.org/10.1093/icesjms/fsp056

Russell, F.S. (1976). The eggs and planktonic stages of British marine fishes. London - New York - San Francisco. ACADEMIC PRESS, pp. 152-160.

Sabates, A., Martin, P., Lloret, J., \& Raya, V. (2006). Sea warming and fish distribution: the case of the small pelagic fish, Sardinella aurita, in the western Mediterranean. Global change biology, 12(11), 22092219. https://doi.org/10.1111/j.1365-2486.2006.01246.x

Sahin, A., Duzgunes, E. (2019). Spatial and temporal variation in the distribution and abundance of pelagic fish eggs and larvae off Giresun, south-eastern Black Sea, Turkey. Acta Ichthyologica et Piscatoria, 49, Issue 1, 159-169.

Satılmış, H.H., Bat L., Özdemir, Z.B., Üstün, F., Şahin, F., Kıdeyş, A.E., \& Erdem, Y. (2006). Orta Karadeniz'in Sinop Bölgesinde Jelimsi Organizmalar ile Balık Yumurta ve Larvalarının 2002 Yılı Kompozisyonu. Journal of Fisheries \& Aquatic Sciences, 23, Ek/Suppl. (1/1), 135-140.

Satılmıs, H.H., Mavruk, S., Bat, L., \& Avşar, D. (2014). Seasonal Changes of Ichthyoplankton Assemblages of Sinop Coasts in Southern of the Black Sea, Turkey Turkish Journal of Fisheries and Aquatic Sciences, 14, 1-10.

Shlyakhov, V.A., Shlyakhova, O.V., Nadolinsky, V.P., \& Perevalov, O.A. (2018). Fishery and biological parameters of the fisheries, targeting the most important shared stocks of aquatic bioresources of the Black Sea as a basis for their regional assessment. Aquatic Bioresources and Environment, 1(1), 86-103 (in Russian).

Tkach, A.V., Glushchenko, T.I., \& Zagorodnyaya, Yu.A. (1991). Nutrition of larvae and fries of Black-Sea sprat Sprattus sprattus phalericus (Risso). Ecology of the sea. (Ecologiya morya), 37, 56-61 (in Russian).

Walther, G., Post, E., Convey, P., Menzel, A., Parmesan, C., Beebee, T.J.C., ... Bairlein, F. (2002). Ecological responses to recent climate change. Nature, 416, 389-395. https://doi.org/10.1038/416389a

Ware, D. M., \& Tanasichuk, R. W. (1989). Biological Basis of Maturation and Spawning Waves in Pacific Herring (Clupea harengus pallasi). Canadian Journal of Fisheries and Aquatic Sciences, 46(10): 1776-1784. https://doi.org/10.1139/f89-225

Weinert, M., Mathis, M., Kröncke, I., Neumann, H., Pohlmann, T., \& Reiss, H. (2016). Modelling climate change effects on benthos: Distributional shifts in the North Sea from 2001 to 2099. Estuarine, Coastal and Shelf Science, 175, 157-168. https://doi.org/10.1016/j.ecss.2016.03.024 